\title{
MULHERES (DE) CORAGEM: POR UM MUNDO MAIS JUSTO
}

Resenha do livro Mulheres (de) coragem: por um mundo mais justo, de Maria do Céu Pires. $1^{\text {a }}$ ed. Lisboa: Edições Colibri, 2018, 167p.

LIBERATO, Ermelinda ${ }^{1}$

A gênese de um sistema desigual entre homens e mulheres, assente na condição de sujeição, subjugação, marginalização, ao longo de séculos, categorizou o sexo feminino como secundário em relação ao sexo masculino, em todas as dimensões e campos de conhecimento, não sendo o campo da filosofia uma exceção, condicionando, deste modo, o (re)conhecimento do trabalho por elas desenvolvido, bem como as suas competências e qualidades. E é precisamente com o intuito de "dar visibilidade às mulheres, que muitas vezes, ficaram na sombra" (p. 8) e por considerar essa ausência uma inverdade, que Maria do Céu Pires assume a responsabilidade de contribuir para a desconstrução dessa opacidade, identificando algumas mulheres (de) coragem, que ao longo do tempo, lutaram em prol do respeito, dignidade, justiça e defesa da sua condição biológica, bem como do seu papel na sociedade.

Ao longo das 167 páginas do livro, a autora, professora de filosofia e igualmente pesquisadora, com diversas publicações versando sobre questões de ética, cidadania, direitos humanos e filosofia, procura dar resposta a muitas das suas inquietações, com destaque para a questão da existência, ou não, de filósofas ao longo da história. E é a própria que nos informa sobre a divisão da obra, "em duas partes distintas" (p. 7). A primeira - às voltas com o passado e com o futuro: outras possibilidades - "integra um conjunto de pequenos ensaios cuja origem se situa em trabalhos e comunicações realizadas em contex to acadêmico nos cursos de mestrado e doutoramento em filosofia na Universidade de Évora" (p. 7). A segunda - as múltiplas vozes

\footnotetext{
${ }^{11}$ Professora auxiliar no Instituto Superior de Ciências da Comunicação (ISUCIC) em Luanda, Angola e Pesquisadora do Centros de Estudos Internacionais do Instituto Universitário de Lisboa (CEI-IUL). Contato: ermelinda.liberato@gmail.com
} 
do inconformismo - a partir da página 95 até ao final, apresenta "pequenas notas biográficas de mulheres que se destacaram pelo seu pensamento" (p. 7) e defesa em torno dos direitos das mulheres, desde a Idade Antiga à Idade Contemporânea.

Nessa esteira, ficamos a conhecer melhor, nalguns casos, ou simplesmente a conhecer, noutros, o legado de mulheres como: Hipatia de Alexandria (370-415) "a única [mulher] que dirigiu a Academia de Alexandria" (p. 95), Christine de Pizan (1364-1430) a "primeira escritora europeia" (p. 97) que sempre primou pelo "acesso das mulheres à educação e a sua intervenção no espaço público" (p. 98), Olympe de Gouges (1748-1793) a defensora da democracia e dos direitos das mulheres, Emma Goldman (1869-1740) a insubmissa anarquista, Clara Zetkin (1857-1933), Simone Weil (1909-1943) a “inconformista por natureza” (p. 105), Maria Zambrano (1904-1991), Teresa Forcades (1966-), Simone Veil (1927-2017), Maria de Lourdes Pintassilgo (1930-2004) primeira mulher a exercer o cargo de $1^{\circ}$ ministro em Portugal, Martha Nussbaum (1947-), Victoria Camps (1941-), Agnes Heller (1929-2019), Hildegarda Von Bingen (1098-1179), Aspásia de Mileto (470-410 a.c), Rosa Luxemburgo (1871-1919), Maria Coroada, Maria Lama (1893-1983) a autora da primeira reportagem sobre as condições de vida das mulheres portuguesas: As mulheres do meu país, Adela Cortina, Seyla Bebhabib (1950-), Nancy Fraser (1947-) e Fernanda Henriques.

Construído e alicerçado em pesquisa bibliográfica e de arquivo, como bem comprovam o bom enquadramento e sintetização do material, a obra destina-se ao público em geral e a utilização de uma linguagem coloquial e fluída, bem como a organização e apresentação da informação são disso um exemplo. A grande importância da mesma, que vale a pena ler e analisar, reside, acima de tudo, no fato de levar-nos a refletir, não somente a questão da produção filosófica por parte de mulheres, mas igualmente, a necessidade de explorarmos essas obras como tendo sido escritas por mulheres, com as "suas autenticidades e inautenticidades" (p. 13). A obra tem ainda como missão transportar-nos para o interior da filosofia enquanto campo do saber, indo para além deste, na medida em que este se ramifica para outras áreas de cognoscibilidade, e consequentemente, outros tipos de gnosis, nomeadamente, empírico, científico e teológico.

Não se trata somente de desconstruir a ideia da ausência de mulheres filósofas, ou, como afirma no seu prefácio, o Professor e filósofo André Barata, se "há um ponto de vista feminino autêntico" (p. 13), mas sobretudo reconhecer o seu trabalho, a sua influência e a sua participação na vida social a todos os níveis. Pela riqueza da informação apresentada, estamos, sem dúvidas, perante um livro de consulta obrigatória, para qualquer ramo do saber, afinal, "a questão do Jangada | nr. 15, jan/jun, 2020 | ISSN 2317-4722 
feminismo não é uma questão de mulheres, mas de toda a humanidade" (p. 36). Por outro lado, essa informação abre caminhos para futuras leituras e pesquisas sobre as diferentes temáticas abordadas, numa perspetiva interdisciplinar, alimentando desse modo o debate científico e a produção de conhecimento, que não deve ser condicionado por estereótipos biológicos ignorantemente criados, culturalmente alimentados, socialmente enraizados e historicamente "cristalizados".

Pela sua importância, não podemos igualmente deixar de referir aspetos que a podem fragilizar, como o fato da autora não identificar filósofas fora do espaço ocidental, nomeadamente, América Latina, África e Ásia, o que, para os menos atentos, pode criar a ideia que o ocidente é o berço do conhecimento e do saber, bem como, a inexistência das mesmas nesses espaços. Estamos em crer que seja apenas uma primeira abordagem sobre a temática e de uma pesquisa ainda em desenvolvimento, e se assim for, ficamos a aguardar, ansiosos, por mais informações. Por outro lado, sentimos igualmente falta de um melhor aprofundamento sobre o impacto do trabalho destas mulheres corajosas na sociedade de cada época e na atualidade, ou seja, a flor que germinou da semente por elas lançadas, assim como o jardim florido daí resultante.

Trata-se de fato de mulheres (de) coragem, ou seja, mulheres corajosas e imbuídas de coragem, que se debateram por um mundo mais justo. A compreensão dessa luta só é possível se cada um de nós recuar no tempo e analisar como era realmente a condição social das mulheres em todas as dimensões: econômica, social, política, cultural e espiritual. E aqui, uma vez mais, advogamos a interdisciplinaridade, ou seja, aos outros campos do saber, para que ajudem a desconstruir as ideias pré-concebidas sobre a secundarização do sexo feminino. Cabe assim, a todos os cidadãos, a tarefa de dar continuidade a esse trabalho, em prol dos Direitos Humanos e do desenvolvimento social e humano na sua plenitude.

\section{REFERÊNCIAS BIBLIOGRÁFICAS}

PIRES, Maria do Céu. Mulheres (de) coragem: por um mundo mais justo. $1^{\text {a }}$ ed. Lisboa: Edições Colibri, 2018. 